\title{
From Religionless Christianity to Immanent Grace: Bonhoeffer's Legacy in Badiou
}

\author{
Jakub Urbaniak / University of Pretoria*
}

\begin{abstract}
The glory of God is the human person fully alive. ${ }^{\mathrm{i}}$
In Christ we are invited to participate in the reality of God and the reality of the world at the same time, the one not without the other. ${ }^{\mathrm{ii}}$

Resurrection is that on the basis of which life's center of gravity comes to reside in life.
\end{abstract}

\section{INTRODUCTION}

This paper seeks to answer the question: In what sense can Alain Badiou's idea of evental grace, conceived of as radically immanent, be understood as the continuation of the legacy of Dietrich Bonhoeffer's nonreligious interpretation? The thematic scope of my analysis is determined by two factors: first, the notions of "religionless Christianity" and "immanent grace" which, as I will argue, despite the evident discrepancy between Bonhoeffer's and Badiou's ontological backgrounds, allow for grasping some analogies between both their general insights and particular views and, second, the willingness to preserve the integrity of each approach. In order to meet the latter requirement I will, first, examine the contexts of Bonhoeffer's concept of worldly faith and Badiou's concept of immanently actual infinity one by one, through the lens of their respective agendas. Only then several analogies among them will be suggested by pointing to the essential continuity of Bonhoeffer's legacy in Badiou with concurrent discontinuity regarding both the ontological basis and the theological implications of their views. Finally, I will suggest a possible message that the trajectory of thought indicated by Bonhoeffer and Badiou might convey to Christianity today.

\footnotetext{
*I wish to thank my mentor and friend Dr Judith Coyle, IHM, from St Augustine College of South Africa who continues to support me academically and spiritually.
} 
It ought to be mentioned that while Bonhoeffer's theology constitutes the proper and direct object of this study, my treatment of Badiou's philosophy assumes an effort of appropriating his thought theologically, which in itself constitutes an unobvious and often audacious task.

\section{Searching Christ's Presence in the World Come of Age}

A German Lutheran pastor-martyr and one of the most influential theologians of the last century, Dietrich Bonhoeffer continues to inspire and puzzle Christian thinkers of various denominations and theological schools. Overshadowed by the dramatic events of his life that came to an end on April 9 $9^{\text {th }}, 1945$ at Flossenbürg, his theology has nonetheless provoked numerous responses. In particular, his notion of "religionless" has received various interpretations. When Bonhoeffer predicts the religionless age, some celebrate him as an "elemental believer" (B. Jaspert) or as a "religious naturalist" (J. Macquarrie), while others reproach him as an "atheist" (A. MacIntyre) or "secularist" (A. Leon). Also many of the "death of God" theologians in the 1960s saw Bonhoeffer as their patron (cf. W. Hamilton). ${ }^{\text {iv }}$ As Wüstenberg rightly points out, to prevent "nonreligious interpretation" from degenerating into a slogan for a wide range of theological trends one cannot allow certain catch-phrases, such as "religionless Christianity," to be worked up into systems of thought sharply opposed to Bonhoeffer's basic Christian theology-not least his Christology. ${ }^{\mathrm{v}}$

"What is bothering me incessantly is the question what Christianity really is, or indeed who Christ really is, for us today." ${ }^{\mathrm{vi}}$ These concerns constitute the organizing principle, the true North Star in Bonhoeffer's life and theology. From that point of view, the topic of religion as such is not even of central significance for the cluster of problems surrounding the nonreligious interpretation. Bonhoeffer's systematic-theological focus does not reside in the critique of religion in the first place ${ }^{\mathrm{vii}}$ but points rather to the Christological 
question (What shape does Christ take in our world?) and its ecclesiological implications (How does the church, the community of disciples founded in Christ's name, make itself manifest in the midst of the world come of age? $\left.?^{\text {viii }}\right)$. Indeed, when Bonhoeffer asks the question of what Christianity is for us, the "us" aspect takes central focus: Who are we? And what has the world's maturation brought about in our time? ${ }^{\mathrm{ix}}$ Bonhoeffer's short answer is: the historical demise of religion. In the midst of the growing maturation of the world, people become increasingly nonreligious. ${ }^{\mathrm{x}}$ Paradoxically, the world come of age is seen by Bonhoeffer as "more godless and for just that reason perhaps closer to God than the world that has not come of age," ${ }^{\mathrm{xi}}$ i.e., the world of religion in which God was de facto an idol, a deus ex machina. Thus the maturity of the world, the fact that humanity is able to arrange itself without the tutelage of religion or God, is no longer the occasion for polemics or apologetics; instead of demonizing worldliness, the church should rather welcome it as a stage in the journey towards human autonomy and ask, "How can Christ also become the Lord over those who are religionless?"xii

When it comes to Bonhoeffer's critique of religion, many scholars make the mistake of presupposing him to be operating with a fixed concept of religion. In fact, in his writings "religion" is never strictly defined, rather it appears as the "formal, negative foil against which other important ideas are subjectively explicated."xiii The path taken by Bonhoeffer's treatment of religion leads from a positive estimation of religion to a critique of religion and finally to religionlessness. ${ }^{\text {xiv }}$ Bonhoeffer's negative evaluation of religion was due, in the first place, to the historical reality of one of humanity's most soulless moments, the Holocaust: Christian religion, as his country knew it, had proven not only impotent in the struggle against the National Socialists, but indeed complicit in their crimes. ${ }^{\mathrm{xv}}$ The less immediate reason for his critique, though still of a contextual character, is to be found in religion's entering history as a "substitute" for faith. As a historic concept, religion has been introduced 
by the Deists, culminated in cultural Protestantism and ultimately came to an end in dialectical theology thus becoming historically obsolete. ${ }^{\mathrm{xvi}}$ Bonhoeffer sees the Western form of Christianity as a "preliminary stage to a complete absence of religion," and a mere "garment of Christianity." ${ }^{\text {xvii }}$ However, it has to be stressed that it was not just the historical and cultural factors that caused Bonhoeffer to pursue his "nonreligious interpretation." The more essential (systematic-theological) reasons for his critique of religion will be mentioned in due course.

From the perspective of influence, the nonreligious interpretation represents a combination of Karl Barth's theological critique of religion ${ }^{\text {xviii }}$ and Wilhelm Dilthey's philosophical historicism. ${ }^{\text {xix }}$ Both Bonhoeffer and Barth believed that "the concept of religion developed by liberal theology replaced the concept of faith of Reformational theology." ${ }^{\mathrm{xx}}$ In brief, theology became anthropology. ${ }^{\mathrm{xxi}}$ In this sense, Bonhoeffer accuses the "religious $a$ priori" of humankind of being merely a "historically conditioned and transient form of human self-expression." ${ }^{x x i i}$ However, Bonhoeffer is obviously going beyond Barth's critique of religion insofar as he not only criticises religion but intends to get along without it. ${ }^{\text {xiii }}$ The "logical conclusion" of the critique of religion is for Bonhoeffer a "nonreligious interpretation" which never appears in Barth and which can no longer be interpreted against the background of dialectical theology. Once again, its pivotal elements will be examined shortly in connection with the philosophy of Badiou.

\section{Philosophizing on ResurRection as a Truth-Event}

Alain Badiou is seen by many as one of the most idiosyncratic and thought-provoking European philosophers today. ${ }^{\text {xxiv }}$ According to Badiou, our embeddedness in the customs and opinions of the world we inhabit is structurally susceptible to disruptions that compel us to decide a new way of being. ${ }^{\mathrm{xxv}}$ Such disruptions or ruptures (truth-events) bring about a 
transformation of the social animal that one was into the human subject one is to become; Badiou refers to this process as "subjectivation:"xxvi "A socialized animal is convoked by certain circumstances to become a subject-or rather, to enter into the composing of a subject." $x x v i i$ In the same vein, Badiou, who identifies himself with an anti-postmodern strand of continental philosophy, diagnoses the reasons for the illness of contemporary philosophy in its various forms: the hermeneutic, analytic or postmodern orientations of philosophy "are too compatible with our world to be able to sustain the rupture or distance that philosophy requires." $x x v i i i$ In this case, the rupture assumes two things, namely the rejection of the misconception that language is the ultimate horizon of human existence (the reversal of the so-called linguistic turn) and the philosophical interruption of the speedy process of history by establishing a fixed and unconditional point within discourse. Curing philosophy, or making again true philosophy of it, is the task to which Badiou has set himself and which he sees himself fulfilling in his doctrine of the event, ${ }^{\text {xxix }}$ which also entails a new theory of the subject and a new understanding of truth. ${ }^{\mathrm{xx}}$

Badiou attempts to rethink the relationship of the infinite and the finite. Translated into theological terms, this goal could be expressed by the following questions: Is it possible to think of grace in conjunction with immanence? Can the infinity of grace be thought as immanently actual, rather than as transcendent or potential? Or simply, Can we, today, think the nearness of grace? ${ }^{\mathrm{xxxi}}$ Badiou basically identifies ontology, i.e. the science of being qua being, with mathematics. ${ }^{\text {xxii }}$ He frames his understanding of infinity in the context of set theory, as conceived by Georg Cantor in the 1870s, which is a way of coherently conceptualizing a hierarchy of actual infinities. However, unlike Cantor, Badiou argues that modern science requires us to rethink philosophical treatments of infinity without referring to God and thus to develop a "rigorously immanent ontology capable of eluding all of the traditional traps of transcendence." ${ }^{x x i i i}$ In his magnum opus, Being and Event, he provides 
ontological "schemas" appropriate to an infinite ontology which then supplies the context for a conception of an event of grace. Though dense in its formal complexity, Badiou's approach allows him to develop a general procedure for extending the consequences of an event and, ultimately, for articulating an event as a truth. In this sense, what he develops deserves to be called "meta-ontology."xxxiv

The "care of truths" that may follow from a grace leads Badiou to Saint Paul in whom he sees "the first great theoretician of event as the source of universal truth." ${ }^{\mathrm{xxxv}}$ As Depoortere notices, "the attention given to Saint Paul by a number of contemporary thinkers, today mainly by atheist and materialist philosophers who have, like Badiou, close links with Marxism, is one of the most remarkable trends within the so-called 'turn to religion' in recent contemporary philosophy." ${ }^{x x x v i}$ Philosophical interpretations of Paul can be traced back to Hegel, Kierkegaard, Nietzsche, and Heidegger. More recent followers of this tradition include, inter alia, Lyotard, Ricoeur, Marion, Agamben, Žižek, and Badiou. ${ }^{\text {xxxvii }}$ In his shamelessly philosophical interpretation of Paul, Badiou treats the Pauline letters as if their primary concern was identical with his own contemporary question regarding the general conditions for a new truth. ${ }^{\text {xxviii }}$ It has to be mentioned that what underlies Badiou's "theoretical" reading of Paul is his search for "a new militant figure," one who could replace the party militant, i.e., the type of militant figure founded by Lenin which has now become obsolete. ${ }^{\text {xxxix }}$ Badiou presents the apostle as an eminent example of a "revolutionary subjectivity which emerges in the wake of an event and consists in one's fidelity to that event." ${ }^{\mathrm{xl}}$ Badiou's intention is neither historicizing nor exegetical, but rather subjective through and through, confined to the relation that Paul's texts bear to his own thought. Based on a non-hermeneutical reading of the Pauline letters he proposes a picture of Paul as a "poetthinker of the event," ${ }^{x l i}$ in which the dominant feature is his commitment to universal truth. 
This truth "is not produced by objective circumstances-a people, a kingdom, a city or a social class-but by a single event," ${ }^{\text {xlii }}$ namely the resurrection.

In the manner of Paul's discussion of the resurrection, Badiou discovers the epistemological basis for the apprehension of universal truth. ${ }^{\text {xliii }}$ However, he is concerned solely with the formal structure of Paul's truth-claim, while explicitly rejecting Paul's cosmology and the whole content of the Christian doctrine. For this self-confessed atheist, the resurrection is a fable from which he means "to extract a formal, wholly secularised conception of grace." ${ }^{\text {xliv }}$ What is more, it stands outside of the four genres of event-love, art, science, and politics-that he considers potential bearers of truth today. ${ }^{\text {xlv }}$ "This does not merely imply that the first and greatest theoretician of the truth-event proclaimed what was only a semblance of an event, ironic as that would be. ${ }^{\text {xlvi }}$ It also means that Badiou has denied theology, including Paul's, any place in the discourse of truth." xlvii

\section{BONHOEFFER AND BADIOU: DISCONTINUITY WITHIN CONTINUITY}

The attempt to juxtapose the Christological-ecclesiological insights of a pastor-theologian with the ontological deliberations of a materialist philosopher for whom Christ's resurrection is merely an analogue, in search of significant parallels, may appear as an odd enterprise. It seems problematic whether, as theologians, we are genuinely able to take issue with Badiou on his own terms, i.e., to simply accept his meta-ontology, including the claim that it disproves God. To meet this challenge it will be necessary to creatively exploit the theological potential of Badiou's reading of Paul, while-at least to an extent-bracketing his declared atheism. ${ }^{\text {xlviii }}$

Since Badiou is transparent about the extent to which he is demythologizing Paul and Christianity in general, he should not be accused of any covert attempt to usurp the epistles or the tradition. ${ }^{\text {xlix }}$ What is more, he knows full well that in altering a non-theological reading of 
Paul's texts he is, in many respects, reading against the intentions of the apostle. Therefore, to criticize his interpretation on that basis would be of limited effectiveness. ${ }^{1}$ Rather, let's venture a similar operation on Badiou himself and try to theologize, in turn, on his "godless philosophy" in dialogue with Bonhoeffer's nonreligious interpretation of Christianity. ${ }^{\text {li }}$

\section{Grace at Work in the Midst of Life}

As we have seen, for Bonhoeffer the world come of age acts as a midwife to the gospel: it enables us to recognize God in the midst of our life and "not merely at the limits of our possibilities."lii As for Badiou, he postulates "restoring the universal to its pure secularity, here and now." ${ }^{\text {liii }}$ While Bonhoeffer derives his "worldly-nonreligious interpretation of Christian concepts" ${ }^{\text {liv }}$ from theologically reflecting on the mystery of the incarnation, Badiou's avowedly secular approach to evental grace is based purely on his ontological treatment of the resurrection.

In Bonhoeffer's writings, the topics of "holy worldliness" and the centrality of life emerge naturally from his critique of religion. In Tegel theology, the old alternative "religion or faith" is replaced with the new one: "religion or life:" "Jesus calls us not to a new religion, but to life."lv Bonhoeffer basically interprets the concept of faith as the concept of life, the abbreviated thesis being: to live so as to believe. Thus faith becomes de facto the ontic presupposition of life. ${ }^{\text {lvi }}$ "Being a Christian does not mean being religious in a certain way ... rather, it means being a human being." ${ }^{\text {lvii }}$ God's reality cannot be divided into religion on the one hand and earthly reality on the other; God is either "completely real" in the world, congruent with it, or not real at all-tertium non datur. . viii "In Christ we are invited to participate in the reality of God and the reality of the world at the same time, the one not without the other."lix What is of Christ is within our reach only through what is of the world: there is no "island of the blessed," no quiet little religious room where we are alone, "no place 
where the Christian can withdraw from the world either outwardly or within the inner sphere, ${ }^{\prime \prime x}$ pleasant as this might be. As Christ was wholly the world's, so the Christian should be wholly Christ's and simultaneously stand in the world; worldly existence and Christian existence are to be fully integrated. While religion separates the world into two spheres, sacred and secular, the God of religionless Christianity calls us to understand all reality as sacred and sacramental, as "holiness incognito" which never manifests itself in terms of other-worldliness but can be made known only through our willingness to manifest it. "What is important, therefore, is to be part of God's and the world's reality in Jesus Christ today in such a way that it is impossible for me to experience the reality of God without the reality of the world or the reality of the world without the reality of God." ${ }^{\text {Ixi }}$ The radicalism of this statement, which draws its intuition from the "logic of incarnation," is striking.

Nietzsche reproached Paul for shifting "the center of gravity of the entire existence beyond this existence-into the lie of the 'resurrected' Jesus." ${ }^{\text {Ixii }}$ Badiou, on the contrary, sees in the resurrection "that on the basis of which life's center of gravity comes to reside in life, whereas previously, being situated in the Law, it organized life's subsumption by death."1xiii Resurrection establishes the unconditional point of interruption, the point of discontinuing death's rule and, hence, allowing life to take revenge on death here and now, enabling the subject to "live affirmatively, according to the spirit, rather than negatively, according to the flesh, which is the thought of death." ${ }^{x i v}$ This usage of the categories of "life" and "death" corresponds to the hope that humanity can now vanquish death and affirm life in the contingent sense, rather than by trusting in a literal or physical promise of resurrection: death and life are paths that can be chosen here and now, there is no need to transpose them into the transcendent dimension. In order for ontology to be ultimately freed from ontotheological trappings Badiou adopts "the thesis of the infinity of being" itself. ${ }^{\text {lxv }}$ Since infinity joins immanence and breaks with transcendence, no resort to other-worldliness is required: infinite 
multiplicity is simply and immanently what there is. ${ }^{\text {lxvi }}$ As Badiou's interpreter Adam Miller points out, against such a background the notion of "immanent grace" does not dissolve into paradox and contradiction but is actually thinkable. ${ }^{\text {lxvii }}$

In the traditional model of a universe that is metaphysically grounded in a supernatural world, the intervention of grace occurs when the transcendent reality impinges on our own. Even though grace thus comprehended may have immanent effects, it has, nonetheless, a supernatural locus. ${ }^{\text {lxviii }}$ To overcome this difficulty the novel difference produced by grace must be thinkable as a difference proper to immanence itself. ${ }^{\text {lxix }}$ Drawing on the reflection of Paul, Jean-Luc Marion, and Alain Badiou, Miller argues that "it is possible to think grace as an immanent novelty that is actually infinite, that is to think it in terms of both immanence and actuality." ${ }^{\mathrm{xx}}$ The reason why Paul's writings break ground for the thought of an immanent grace is that the resurrection of Jesus puts Paul in a peculiar conceptual position: he is forced to think about grace given the fact that the Messiah has already come and actually accomplished our redemption. "Though Paul's thought does not proceed without reference to a supernatural order beyond our own, he still must account for how God's grace can be both immanent (it is already here) and actually given (it is not simply latently potential)-all despite the fact that the world has not ended but continues on as if nothing has happened." ${ }^{1 x x i}$ Badiou follows in Paul's steps, as it were, freeing his "theory of truth" from unnecessary reference to transcendence.

Both Bonhoeffer and Badiou direct our attention towards this-worldliness / immanence, though they do so for different reasons. While Bonhoeffer claims that God makes God's own self communicable but through what is human, Badiou insists that the infinite as such is not divine but radically immanent, i.e., equivalent to being qua being. From an ontological point of view, their positions can be seen as parallel only in a very limited sense. However, if we look at them through the prism of the question of God's "availability" to the human being or his 
presence in the world, the conception of immanent grace, based on Badiou's ontology, can offer a surprisingly adequate answer to Bonhoeffer's Christological concerns: Who is Christ for us today, in the world come of age?

\section{Being for Others and Declaring the Event: The Only "Weapons" of the Believer}

In Discipleship Bonhoeffer writes, "The word of Jesus keeps its honor, its strength, and power among us only by our acting on it. Then a storm can sweep over the house, but it cannot tear apart the unity with Jesus created by his word." ${ }^{\text {lxxii }}$ By stressing that the gospel is bodiless in the world unless we incorporate it through our action Bonhoeffer by no means attempts to reduce the Christian ethos to its horizontal dimension. ${ }^{\text {lxiii }}$ Rather, he wants us to recognize the unique means and realization of Jesus's being for others in the world today in our own readiness to follow in his footsteps. The negative side of this truth is reflected in his bold claim that "neither knowledge, nor morality, nor religion leads to God." ${ }^{\text {xxiv }}$ For Badiou, the event puts language into deadlock which is folly (mōria) for Greek discourse and a scandal (skandalon) for Jewish discourse. ${ }^{\text {lxxv }}$ While the former demands logical reasons, the latter "insists on a sign of divine power and sees in Christ nothing but weakness, abjection, and contemptible peripeteia." ${ }^{1 x x v i}$ As a consequence, the apostle who does not have prophetic or miraculous guarantees, arguments or proofs, at his disposal can only declare "an unheard of possibility, one dependent on evental grace" ${ }^{\text {lxxvii }}$ of resurrection and, then, remain faithful to it by the "rude harshness of public action." ${ }^{\text {lxxviii }}$ In this section, I will examine Bonhoeffer's critique of religion and morality as analogical to Badiou's approach to Greek and Jewish discourses as well as Bonhoeffer's notion of participating in Jesus's being for others and Badiou's understanding of declaration.

Bonhoeffer considers religion and morality to be "the greatest danger for recognizing divine grace, since they bear within themselves the seed prompting us to seek our path to God 
ourselves." ${ }^{\text {Ixxix }}$ Knowledge, either religious or moral, represents to him the path from human beings to God which unavoidably "leads to the idol of our hearts which we have formed after our own image." ${ }^{\text {lxxx }}$ In his theology, Bonhoeffer focuses on the critique of religion, whereas the critique of morality remains implicit. First, he accuses religion of absolutist tendencies and partiality that cause it to fail to concur with life. ${ }^{\text {lxxxi }}$ Religion dichotomizes the world along the lines of the sacred and the profane, the spiritual and the secular, the saved and the damned, and perhaps most insidiously, the good and the evil, ${ }^{\text {lxxii }}$ which is radically opposed to the "totality" and "integrity" of a lived faith. Second, religious discourse is defined in terms of temporarily conditioned presuppositions of metaphysics and inwardness (or individualism). ${ }^{\text {lxxiii }}$ Metaphysics refers here to the religious "habit of seeing God behind things, as something not of this world (meta-physical!);"1xxxiv religion thus understood becomes a vehicle of other-worldliness. Individualism, on the other hand, generates the religious focus on sin and personal salvation, and thus reserves for God the "inside" of the human being. None of them allows Christ to be the Lord of the whole world and the whole of the human person. ${ }^{\text {lxxxv }}$ The most essential (theological) objection against religion is conveyed in Bonhoeffer's conviction that God mended the sundering of religion from life by living in Christ a full, undivided life as a full human being: "God's coming is a criticism of all religion." emerges from nonreligious interpretation cannot be filled with any sort of speculation-be it metaphysical or moral-but only with a lived, worldly faith: "God comes to human beings, who have nothing other than a space for God, and this empty space, this emptiness in human beings is in Christian language called: faith."

For Badiou, what makes an event "evental" [événementiel] is first and foremost the fact that it evades the order of proof: "There is no proof of the event; nor is the event a proof." ${ }^{\text {"xxxviii }}$ Far from being structural, axiomatic, or legal, it is simply "of the order of what 
occurs" $^{\text {"lxxxix }}$ and thus always singular and hazardous. By insisting on the evental character of declaration, Badiou stresses that it does not declare the meaning of the event (resurrection), but it does simply and emphatically declare the fact of its having happened. ${ }^{\mathrm{xc}}$ Apart from this negative aspect, however, the same evental nature of the truth - i.e., the fact that it can be grasped only through declaration - appears in Badiou as that which accounts for subjectivation. Put simply, only the evental truth constitutes and founds the subject. ${ }^{\text {xci }}$ Paul's situation-and, in a broader sense, the situation of every believer (or "apostle," as Badiou calls the one who declares the event)-can be described as dominated by the rule of two related but distinguishable "regimes of discourse": Jewish discourse and Greek discourse. The prophet who predicts through figures or signs is the figure of the Jewish discourse, whereas the philosopher who attempts to speak of eternal truths is the figure of the Greek one. Together with the specifically Christian (in a strict sense, Pauline) discourse of the evental declaration, they constitute three discourses whose subjective postures are: to demand-to question-to declare. ${ }^{\text {xii }}$ The fourth discourse (miraculous or mystical), according to Badiou, must remain unaddressed: it cannot enter into the realm of preaching, for it is "vain to want to justify a declaratory stance through the appeal of miracle." ${ }^{\text {xciii }}$ The intersection of law (Jewish or Greek) with sin is considered by Badiou the central problem recurring in almost all the Pauline epistles. Sin is not conceived of in terms of individual fault but as "living thought's inability to prescribe action." ${ }^{x c i v}$ If we were able to save ourselves, we would not be in sin. But since it is beyond our capabilities, an event (resurrection) must intervene in order for the oppressive automatism of the law to be interrupted. ${ }^{\mathrm{xcv}}$ As Badiou contends, "Paul's project is to show that a universal logic of salvation cannot be reconciled with any law, be it one that ties thought to the cosmos, or one that fixes the effects of an exceptional election." ${ }^{\text {xcvi }}$ However, Badiou goes further by stating that if the event were transcendent, as Paul maintains, it would be likely to simply duplicate the Jewish logic of 
divine exception and leave the measure of the law intact-hence his conclusion that the event must be of an immanent nature. ${ }^{\text {xcvii }}$

In Badiouan ontology, the role of the absolute infinite (divine) has been taken by "the void" conceived of as the "errant 'place' where each situation is sutured to its being qua pure multiplicity or inconsistency." ${ }^{x c v i i i}$ In other words, "the fundamental ontological characteristic of an event is to inscribe, to name the situated void of that for which it is an event." ${ }^{\text {xcix }}$ According to Welborn, that explains why Paul is seen by Badiou as a foundational figure and the first great theoretician of universal truth:

[U]nlike effective truth-procedures which aim at the production of a universal in the domains of science, art, politics, and love, there occurs with Paul a powerful break ... which deserves to be called 'theoretical', ' because the situated void which Paul's proclamation inscribes and names is nothing other than death itself. Paul's declaration 'Christ is resurrected' blasts open the continuum constructed around death. ${ }^{\text {ci }}$

Reynhout, in turn, in his attempt to appropriate Badiou's thought theologically, comes to the conclusion that allows him to ultimately identify this nameless void with God, thus falling back on Tillich's designations of God as "being-itself" or the "ground of being."cii Depoortere depicts the analogy pointedly: "Just as zero or the empty set cannot be deduced, but has to be decided upon axiomatically, the being of God cannot be demonstrated, but has to be declared." ciii

Let's go back to Bonhoeffer. The God of Jesus, instead of being banished to religious exile-either that of metaphysics or that of inferiority-must be proclaimed and realised in a religionless-worldly manner. A nonreligious interpretation stemming from the movement deeper into the world aims at disclosing the meaning of biblical concepts for our earthly life here and now. ${ }^{\text {civ }}$ What does acting on the words of Jesus mean in practice? Bonhoeffer, whose late theology remains of a fragmentary character, was unable to outline a program of practicing a nonreligious Christian existence in the midst of the world. Yet, he left us several 
guidelines. The content of Christian life in the world come of age, as a guiding concept, is described in his texts either in the pair "prayer" and "discipleship" or is expanded into the triad "prayer," "action," and "waiting." "v "Discipleship" or "righteous action among people" are, in turn, connected with the notion of "being for others." The religionless Christian is "the person who lives from within the transcendent,"cvi i.e., the person who through faith participates in Jesus's being for others. For Bonhoeffer, our relation to God must express itself in a new life in "existence for others," through participation in the being of Jesus, i.e. his incarnation, cross, and resurrection. ${ }^{\text {cvii }}$ Belonging wholly to the world and living for others without claiming cultural or spiritual privilege, without regarding oneself as "religiously" favored is then essential, decisive, and normative to religionless faith. Only such an attitude can enable a Christian to overcome the forces that separate the world from God, religion from reality, and faith from life. ${ }^{\text {cviii }}$ In Bonhoeffer's view, the previous religious language of the church was incapable of expressing what life in Christ and discipleship mean. Worldly faith embedded in being for others requires an adequate language capable of evading the trappings of metaphysics on the one hand and those of inwardness on the other. Bonhoeffer prophesies: "It will be a new language, perhaps completely unreligious, but liberating and redemptive, like the language of Jesus." ${ }^{\text {cix }}$

According to Badiou, the event is logical rather than phenomenological, which is to say, it draws from presentation itself. Thus the initial intervention is purely "of the order of declaration." ${ }^{\mathrm{cx}}$ It does not declare the meaning of an event, but it simply and emphatically declares the fact of its having happened: "there is an event, it has consequences, and these consequences need to be faithfully elaborated in relation to the status quo that has been interrupted." ${ }^{\text {cxi }}$ From the conditions of his own "conversion" Paul draws the consequence that one can only begin from the declaration of the resurrection being the "real of faith," a declaration which is in essence subjective, for no preconstituted subset can support it. ${ }^{\text {cxii }}$ The 
apostle must be accountable only for what others see and hear, i.e., for his or her declaration. ${ }^{\text {cxiii }}$ It is the essence of faith to publicly declare itself; even though private conviction is required, only the public confession of faith installs the subject in the perspective of salvation. ${ }^{\text {cxiv }}$ The truth of a declaration, being without proof or visibility, emerges at that point where knowledge, be it empirical or conceptual, breaks down. Hence Paul's "antiphilosophy:" apostolic declaration stems from and gives expression to a pure fidelity toward the possibility opened by the event. ${ }^{\mathrm{cxv}}$ If truths lack objective strength, then their substance must be provided by the subjective persistence of fidelity which supplies the truth procedure with consistency. ${ }^{\text {cxvi }}$ The substance of truth is faith. Fidelity is to be seen not as "a capacity, a subjective quantity, or a virtue" but as "a functional relation to an event."cxvii Miller rightly points out that "whether finitude or infinity prevails depends on the decision that is made in relation to the event. Only an intervention, by declaring the existence of the event, is able to decide in favor of infinity." ${ }^{\text {cxviii }}$ In other words, the relevance of the event to the life of others is contingent exclusively on the apostle's fidelity towards that event.

Since the truth is proclaimed and not proven, it implies the "language of the naked event, which alone captures thought." ${ }^{\text {cxix }}$ Badiou describes it only in negative terms: "What imposes the invention of a new discourse, and of a subjectivity that is neither philosophical nor prophetic (the apostle), is precisely that it is only by means of such invention that the event finds a welcome and an existence in language. For established languages, it is inadmissible because it is genuinely unnamable." ${ }^{\text {cxx }}$ But he gives us a hint as to how a language in which "event finds a welcome and an existence" might look like when he says that all true names to which the subject of a truth lays claim are, like Jesus's name (cf. Phil. 2:9), i.e., above every name. "They let themselves be inflected and declared, just as mathematical symbolism does, in every language, according to every custom, and through the traversal of all differences."cxxi 
Bonhoeffer's critique of religion and morality and Badiou's approach to Greek and Jewish discourses share an underlying negative, anti-idolatrous intuition which allows Bonhoeffer to preserve the holistic and gratuitous character of faith concurring with life and which enables Badiou to speak of the content of the "resurrection truth-event" as the exclusive source of the declaration's force. Bonhoeffer focuses on acting on the word of Jesus by the participation in Jesus's being for others, whereas Badiou stresses the importance of declaring the event by the subjective persistence of fidelity that constitutes truth's substance. But in both cases, faith seen as the only accurate response to Jesus's call to discipleship (Bonhoeffer)/the event interrupting the old order (Badiou) presupposes some sort of ontological "empty space" or "void" that makes faith as such possible and results in a new type of language which breaks up with traditional religious discourses.

\section{Theologia Crucis and the Militant Discourse of Weakness: Power in Powerlessness}

Bonhoeffer maintains that what ultimately distinguishes Christians from both pagans and "religious people" is that they stand by God in God's suffering. "'Could you not keep awake one hour?' Jesus asks in Gethsemane. This is the reversal of everything a religious person expects from God. Human beings are called to suffer God's own suffering at the hands of the godless world." between the religious and nonreligious interpretation. Badiou claims, in turn, that the power of a truth is only "fulfilled in weakness itself"cxxiii or, to put it in reverse, that the weakness of the Christian declaration constitutes its only strength. Such a declaration nourishes itself on the "inglorious evidence of weakness," ${ }^{\text {cxiv }}$ At this point, I will probe these two visions of the "power stemming from powerlessness" as well as their Christological contexts and practical ramifications. 
The theme of suffering, which permeates Bonhoeffer's entire theology, in Tegel acquires a place in his critique of religion: Religion is incapable of co-suffering. ${ }^{\text {cxxv }}$ While a religious interpretation springs from the will to power that rests comfortably with the suffering of others in the name of some larger cause, the nonreligious call of Christianity embodies solidarity with the powerless. ${ }^{\text {cxxvi }}$ In his theologia crucis, Bonhoeffer elevates participation in God's own suffering and powerlessness amid worldly life to the level of a Christian attitude par excellence. Unlike the follower of a "religion" understood as a privilege, who cannot be there for others and thus participate in God's suffering in the world, the nonreligious Christian lives by being drawn "into God's messianic suffering in Jesus Christ." ${ }^{\text {cxxvii }}$ One of the reasons why Bonhoeffer resonated so strongly with the theologians of liberation is that he grasped that the way one responds to suffering corresponds in no small measure to the ways that one defines God. ${ }^{\text {cxxviii }}$ The God projected into the other-worldliness is de facto a "false God," a vision of God that often occludes the God found in the gospels, namely the "crucified God" who wins power and space in the world by weakness. Thus the incarnate presence of God in Christ makes Bonhoeffer sensitive to the universality of suffering in the world and leads him to admit that only the suffering God can help. ${ }^{\text {cxxix }}$ Bonhoeffer believed that Christianity must be something more than the cultural constructions of whatever society it is known within; indeed, when necessary, it must take its stand against the prevailing political and moral orders. ${ }^{\text {cxxx }}$ Even though the embrace of a religionless Christianity takes us to a place of suffering the cross, for Bonhoeffer it has nothing to do with escaping the world in individual piety or otherworldly mysticism. Rather by our very immersion and being in the world-sharing its duties, sorrows, and sufferings-we gain the credibility and authority to call the world into question. Willingness to suffer the wounds of the wounded themselves is by no means equivalent to a move to passivity and surrender to worldly powers; rather it constitutes a place of profound power in 
powerlessness. ${ }^{\text {cxxxi }}$ Pugh even speculates that a "religionless Christianity could well take the form of public resistance to the 'way things are'."cxxxii Bonhoeffer stresses, however, that confronting power may never come from our power but from the powerlessness that God's own self experiences in the cross of Jesus. This awareness results in Bonhoeffer's radical conviction regarding the role of ecclesia in the world: "The church can defend its own sphere ... only by battling, not for that sphere but for the salvation of the world. Otherwise the church degenerates into a 'religious society', fighting for its own existence, and thus automatically is no longer God's church in the world."cxxxiii

Therefore, again, Bonhoeffer is trying to think from the incarnation to the world rather than positivistically from grace to the church. ${ }^{\text {cxxxiv }}$ When he speaks of the "appropriation of the world come of age through Jesus Christ," ${ }^{\text {cxxxv }}$ both his Christocentrism and his anthropology are characteristically holistic and all-embracing. He is concerned with the significance of the "life, sayings, deeds, sufferings, and death of Jesus"cxxxvi for the entirety of human life in all its manifestations. One may ask, where in all this is the resurrection? Bonhoeffer often acknowledges that Jesus Christ is the "living Lord"cxxxvii and quite clearly, faith in the resurrection underlies his entire theological reflection. However, as we have seen, his nonreligious interpretation owes much more to the truth of the incarnation. Throughout his life Bonhoeffer meditated on how the reality of God enters the world through the incarnation found in Jesus Christ and how through this act we can discover the divine intention regarding our own life as well as that of the church. His understanding of thisworldliness is impregnated with the Chalcedonian doctrine of the two natures in Jesus: "Just as the reality of God has entered the reality of the world in Christ, what is Christian cannot be had otherwise than in what is worldly, the 'supernatural' only in the natural, the holy only in the profane, the revelational only in the rational." ${ }^{\text {cxxxviii }}$ It can be said that the nonreligious interpretation is a "life-Christological interpretation relating Christian faith and life come of 
age to one another"cxxxix that aims at inventing the new language capable of grasping the ultimate meaning that Christ's incarnation bears for this-worldliness.

As we have seen, for Badiou proceeding from the truth-event delivers no law and thus no form of mastery, be it that of the wise man (sic) or the prophet. ${ }^{\text {cxl }}$ "If one demands signs, he who performs them in abundance becomes a master for him who demands them. If one questions philosophically, he who can reply becomes a master for the perplexed subject. But he who declares ... does not enter into the logic of the master. ... To declare an event is to become the son of that event." ${ }^{\text {cxli }}$ When Paul leaves for Arabia in order to proclaim the gospel, he is armed solely with a personal event which, nonetheless, provides him with grounds for declaring that impersonal event that is the resurrection. ${ }^{\text {cxlii }}$ As Badiou puts it, Paul "firmly holds to the militant discourse of weakness" ${ }^{\text {cxliii }}$ knowing that he must leave truth to its subjective "voicelessness" for only the work of its declaration ensures its continuation. One of Badiou's central insights is that the militant apparatus of truth can only be achieved by going against the flow of the world, ${ }^{\text {cxliv }}$ which reminds us that-once emptied of its theological content-the structure of Paul's proclamation has, for Badiou, contemporary political significance. In this sense, he discovers in Paul a thinker whose legacy contains revolutionary potential even today" and in whose proclamation of the event of Christ's resurrection as "truth for all" lies the "theoretical basis for continued engagement in revolutionary thought and politics." ${ }^{\text {cxlv }}$

Now, it has to be underscored that, unlike Bonhoeffer, Badiou talks about weakness not in a sense of a personal vulnerability which is an expression of the conformity to Christ through his cross but in the sense of the "formal" weakness of the Christian message. As Zerbe phrases it, in Badiou "evental truth declaration in the modality of weakness does not correspond to one of lived weakness." ${ }^{\text {cxlvi }}$ This results in consequent divergences between Bonhoeffer's thought and his own. First of all, for Badiou the Christian subject is instituted 
not by solidarity with the world's sufferings but through the subject's own declaration of the event. This aspect of Badiou's reflection points to the fundamental role of the act of declaration: "It is not the singularity of the subject that validates what the subject says; it is what he says that founds the singularity of the subject." ${ }^{\text {cxlvii }}$ Paul himself became the subject of the Christian truth suddenly, on the road to Damascus, his "conversion" being the subjective sign of the event proper, i.e., the resurrection of Christ. "Truth, event, subject, and fidelity are thus all part of a single process: truth comes into being via subjects who declare an event and, in so doing, are constituted ('subjectivated' Badiou likes to say) precisely by their faithful and continuous response to the irruption of that revolutionary event." ${ }^{\text {cxlviii }}$ What follows is his dismissal of the significance for Paul of the historical life and death of Jesus. According to Badiou, Paul is "indifferent to the particularities of the living person," he betrays no interest in the details of Jesus's life and ministry, and ultimately "dissolves incarnation in resurrection. ${ }^{\text {cxlix }}$ If this is the case, then Jesus, who is neither a master nor an example, matters only to the extent to which he is the name for what happens to us universally. ${ }^{\mathrm{cl}}$ Badiou also argues for a de-dialecticized Christ-event, which separates out the cross and death as merely the "site" for the event, and resurrection as the event itself. ${ }^{\text {cli }}$ This causes his reading of the Pauline letters to be resolutely criticized by several authors. ${ }^{\text {clii }}$ For instance, Chester points out that seeing in the cross merely the "site of the event" remains inconsistent with regard to Badiou's own conviction that the truth-event always arises from what is excluded, since Paul's logic of exclusion is inextricably tied to God's actions, most fundamentally the self-giving of Jesus in the crucifixion. ${ }^{\text {cliii }}$ It also seems that Badiou fails to appreciate Paul's emphasis on true solidarity with the outcasts as the prime mode of messianic existence; for any embrace of the cross as a model of Christian presence in the world in Badiou's mind is collapsed into a masochistic embrace of suffering in the sense given to it by Nietzsche. ${ }^{\text {cliv }}$ Besides, as Welborn argues, "Badiou's attempt to disjoin death 
from resurrection leads him to place the Pauline concept of the Christ in dangerous proximity to the Nietzschean idea of the Overman as a figure of pure self-affirmation."

Though their understanding of weakness differs significantly, both Bonhoeffer and Badiou draw from it the practical conclusions (ecclesiological in the case of Bonhoeffer and political in the case of Badiou) that reflect their respective Christologies: one centered on the incarnation, the other dissolving incarnation in the resurrection. Whether it is the powerlessness of God experienced by the Christian sufferer who finds himself or herself in the position of the abandoned Christ ${ }^{\text {clvi }}$ or the "formal" powerlessness of the truth-declaration which feeds only on its own content-in either case, it constitutes the subject and paradoxically empowers it to go against the flow of the world whenever the world, in the name of some larger cause, inflicts suffering on the powerless (Bonhoeffer) or prevents the "apostle" from being faithful to the truth-event that has been named in the resurrection (Badiou).

\section{WORLDLY FAITH IN THE EVENT: TOWARDS A RADICAL ECCLESIOLOGY}

In my examination of Bonhoeffer's notion of religionless Christianity and Badiou's notion of evental grace, I have attempted to prove that the latter can be interpreted as the continuation of the former, though only in a sense and to a degree to which radical discontinuity between the two does not occur. Now, drawing on the reflection of both Bonhoeffer and Badiou, I would like to sketch the proposal of possible directions that worldly faith in the Event could take.

The initial, Christological, question underlying Bonhoeffer's theology (Who Christ really is for us today?) led him eventually to the ecclesiological formula: "The church is a church only when it is there for others." ${ }^{\text {clvii }}$ For ecclesia to meet this requirement, it has to develop the tools that will enable it to guard itself from various forms of idolatry, 
commercialism, dogmatism, totalitarianism, sectarianism, and xenophobia that may be produced by its own structures and ideologies. It seems to me that both Bonhoeffer and Badiou have something to say about the challenges to be faced by such a radical ecclesiology.

Few have experienced the consequences of religion being used by the political order as a tool to mobilize forces for its agendas more acutely than Bonhoeffer. Bethge, his closest friend to whom most prison letters were addressed, asks rhetorically, "Is there not concealed behind our religious trends our ungovernable urge toward ... power-in the name of God to do what we want, and in the name of the Christian worldview to stir up and play people against one another?"clviii Those immersed in the forms of religion that legitimate their own culture are particularly susceptible to ignorance regarding the deep connection between religion and the will to power. Unlike religious institutions (in the Bonhoefferian sense), the church that is rooted in Jesus's being for others has the potential to offer the world a vision that relativizes all social orders. ${ }^{\text {clix }}$ Commenting on Matt. 7:21, where Jesus says, "Not all who say to me, 'Lord, Lord', will enter the kingdom of heaven, but only those who do the will of my Father in heaven," Bonhoeffer warns against "a kind of confession of Christ that Jesus rejects because it is in contradiction with doing the will of God." ${ }^{\text {clx }}$ Jesus rejects such a confession, Bonhoeffer, explains, "because it arises out of our own human knowledge of good and evil."clxi Therefore, the ecclesia must always remain aware of the danger consisting in a religious dogmatism that equips the believer with the categories of good and evil without incorporating personal relation with God as the measure against which his or her life is to be discerned. ${ }^{\text {clxii }}$

That should remind us of the two religious dimensions that Bonhoeffer aimed to overcome for the sake of a worldly faith, namely other-worldliness (metaphysics) and inwardness (individualism). By making us servants of the "heavenly God," who does not have the human face of Jesus, religion almost automatically establishes the sphere of the sacred and that of the profane, and in so doing makes us see ourselves as privileged or pure. 
In such a divided reality, those who do not confess our God sooner or later become our enemies. While narrowly comprehended, religious affiliation generates the distinctions that divide us into hostile camps, the Christ of the nonreligious faith "wants us to be in the midst of our enemies, just as she was." ${ }^{\text {clxiii }}$ The religion that Bonhoeffer seeks to deconstruct is the "habit of heart that allows us to approach the world without love, even while declaring that we are doing just the opposite. "clxiv In this sense, Bonhoeffer's holistic approach to life and his Christological radicalism can preclude the church from falling into totalitarianism, on the one hand, and becoming sectarian and xenophobic, on the other. Individualism also constitutes a constant threat to faith, yet in a different way: striving for my own salvation simply goes against the Christian ideal of participation in Jesus's being for others and consequent solidarity with the world's sufferings. Besides, the egocentric focus on one's own salvation that compromises the common good can be easily manipulated into serving diverse political agendas. Indeed, when one's salvation becomes a matter of saving one's own culture, society, country or community, it shows that religion degenerates into what Bonhoeffer calls "pagan wisdom."

Finally, there is another (less obvious) aspect of Bonhoeffer's nonreligious interpretation that may be applied to the threat of "religious commercialism." While reflecting on the meaning of cult and prayer in religionless Christianity, Bonhoeffer directs our attention towards the "arcane discipline" of the early church. Here lies at least a partial answer to the question: "How the type of faith to live in the 'world come of age' might secure its boundaries within the world?"clxvi At first glance, prayer and worship seem to be the epitome of other-worldly religious ritual. However, Bonhoeffer finds them necessary to protect the mysteries of the Christian faith against profanation, ${ }^{\text {clxvii }}$ i.e., against sliding into either other-worldliness or inwardness and thus becoming banal and shallow. This can be interpreted in terms of Bonhoeffer's willingness to prevent the nonreligious interpretation 
from being flattened into a form of liberal humanism, pure anthropocentrism or some sort of prosocial ethical behavior. Despite the fact that in Christ's incarnation God makes God's own self radically available to the world-to the point of abuse, marginalization, and (in our times above all) irrelevance-the church is responsible for preventing the gospel from becoming too available, that is to say, too commercialized, too marketable, too self-evident, too easy to talk about, too amenable to the "evangelistic sales pitch." ${ }^{\text {clxviii }}$ If being a Christian is not to be reduced to believing in certain metaphysical doctrines and practicing certain religious rituals, the church has to keep its rituals and its doctrines, so to speak, as a secret, as a mystery, and as a gift received through revelation-a gift that should be shared with others in such a way that those who accept it are aware of both the value and the cost of discipleship in Christ. All that the world should see on the outside, while observing Christians, is a "secular" and "religionless" being-there-for-others. At the same time, the church cannot forget that the power of Jesus' proclamation of the kingdom of God resides in the realization that "our God" is also the "God of others." A contemporary French theologian Joseph Moingt insists that we have access to God only insofar as we are prepared to forgo attempts at making God "our God," our property, God in our image, the custodian of our past, who is important to us as a confirmation of our common identity-in brief, insofar as we are prepared to let God be "other" and exist for others. ${ }^{\text {clxix }}$ This resonates with Bonhoeffer's own view that the church must understand itself as the church for the world, as the church for others, independent of their religiosity and religion. ${ }^{\text {clxx }}$ This tension between God's "availability" that has to be proclaimed as the good news for the world and the church's mission to protect the mysteries of faith against banalization and commercialization must not be easily resolved: the community of the faithful should build its identity by striving to embrace that paradox.

Badiou also emphasizes that the subjects to the truth of the resurrection, by the very fidelity toward that truth, are enabled to "refuse to submit to the order of the world as it has 
existed and instead struggle for a new one." ${ }^{\text {clxxi }}$ The community of the believers is constituted by their faithfulness toward the event which, in turn, allows them-and only them-to see the truth that it communicates. While the State's interest is always in reforming the world, the believers are not interested in reforming the existing reality but in the birth of a new one. Therefore, those who feed on the truth-event adopt "a necessary distance from the State and from what corresponds to the State in people's consciousness: the apparatus of opinion." Following Paul, Badiou admonishes that "a truth is a serious and concentrated procedure, which must never enter into competition with established opinions." between the opinions and the truth may suggest the same anti-idolatrous tendency that underlies Bonhoeffer's reflection on the arcane discipline: the church must not allow the truth of the resurrection to be "sold" to the world as one of many products, since that would cause the specifically Christian discourse of the evental grace to degenerate into something we might call the "market-discourse" or, somewhat ironically, the "American discourse."

Badiou sees the ecclesia as a "site of contestation that requires nothing less than an active and never-ending pursuit of clarification to remain faithful to the truth-event that is named in the resurrection." ${ }^{\text {clxxiv }}$ According to Hiebert, his reading of Paul helpfully articulates a vision for the shape of the church within the conditions of late capitalism. ${ }^{\text {clxxv }}$ Let us examine this thesis more closely. Hiebert argues that Badiou derives from Pauline ecclesiology the conviction that the mission of the church consists not in reactively overcoming capital but rather in the "vulnerable stance of patiently dwelling within the world [where] capital dominates, and struggling to remain faithful to the event of the resurrection, even if it means that Christ’s own body becomes infected."clxxvi This "struggling universality" (as Žižek puts it) $)^{\text {clxxvii }}$ of the ecclesia may stem only from fidelity to the event which necessitates ongoing clarification. Such a universalism, which by nature adopts what Badiou calls a "militant discourse," is not primarily a reaction to external threats (which would make Badiou's 
position all the more amenable to the mechanized logic of capital), but rather embodies a stance of vulnerability and thus can be expressed only in a "militant discourse of weakness."

If Terry Eagleton is right when he suggests that "for the radical, the real monsters are ourselves," ${ }^{\text {clxxix }}$ then the task of diagnosing the multiple flows of power with which the church is confronted at "the end of history" must be accompanied by a renewed analysis of the ways in which the church itself is the product of these very powers. Going beyond Badiou, this means cultivating an awareness that if the ecclesia is truly to be itself in today's world, instead of hovering on the margins to keep itself pure, it should rather realize that its proclamation of the lordship of Christ depends on a network of complex relationships. That means that, far from seeking uniformity and discipline, disagreement can be welcome and even the authorities can vulnerably put themselves in question. In brief, the church must become "a site of contestation" rather than the "custodian of the fundamentals," a place that is hospitable to conflict and crisis rather than an institution searching, at any cost, for some kernel of unity upon which differing sides can easily agree and move forward. ${ }^{\text {clxxx }}$

In traditional (Augustinian) terms, it means that ecclesia must be semper reformanda, which is to say, it needs to preserve a constant potential for radical reformation that can be drawn only from the novelty of evental grace. The church, like every institution, is susceptible to the tendency of withdrawing into a particularism of its own which can easily lead to its becoming parochial and eventually degenerate into a private but harmless eccentricity of a minority. That is why Badiou's emphasis on the uniqueness of evental grace as the only source of the subject's identity appears to be so relevant. Christ's resurrection summons ecclesia to become a "new Israel," and not a "second Israel," i.e., another particular community alongside Israel and many others; it engenders the courage to be constantly people on the way, boldly crossing all borders, instead of turning the faith in the Resurrected 
into a "heritage of the fathers," an inherited property which reduces the "Father of Jesus Christ" to the "God of the fathers." Put briefly, from the very beginning Christianity has been established as a religion that would surpass religion. ${ }^{\text {clxxxi }}$ (Isn't this what Bonhoeffer means when he states that "Christ does not bring a new religion; rather, he brings God"? $\left.{ }^{\text {clxxxii }}\right)$. Halík points out that such a position is a radical emulation of Saint Paul who presents Christianity, not as an aspect of some orthodoxy or orthopraxis, but as a faith capable of dissociating itself from its past, ridding itself of old customs and certainties, rejecting particularity, and going to others. ${ }^{\text {clxxxiii }}$ In this context, "Paul's crossing of the borders of Israel and setting out for the 'people' (the pagans) should be a paradigm for the entire history of the church." Christians must not make light of the Gospel's novelty by clinging to the past and remaining in the narrow confines of particular traditions functioning within the church, for that would be equivalent to betraying the novelty of the truth-event of the resurrection by entering into competition with established opinions. Badiou reads the Pauline epistles as glad tidings proclaiming that it is possible for something new to happen. In Miller's words, "grace is an interruption of the predictable line that is time, an unforeseeable gap in the rails that sends the world careening down an oblique track to someplace other, the promise that the future need not have already been decided by the past." ${ }^{\text {"lxxxv }}$ Sending us back to that most basic layer of the Christian message Badiou equips us with an unparalleled negative, anti-idolatrous tool to protect the properly understood universalism of the gospel. As Hiebert concludes, "Badiou's vulnerable universalism points toward a radical ecclesiology that is closer to the universalism that is rightly named 'catholicity'."clxxxvi

\section{CONCLUSION}


Contemporary fields of academic philosophy (as diverse as the analytic, hermeneutic, and postmodern traditions) share at least one feature, namely "a profound suspicion of the very word 'truth'."clxxxvii What differentiates Badiou from the majority of philosophers today is his zealous commitment to truth as a universal singularity. This striking characteristic of his thought is one of the reasons why theologians should not dismiss his ontology on the grounds of its being materialist and atheistic. On the other hand, Depoortere admonishes that we must guard against an all-too-easy theological appropriation of Badiou. A quick adoption of his work by theology is impossible, it requires time. ${ }^{\text {clxxxviii }}$ In light of my analysis, it is not difficult to see why. Ultimately, one cannot simply ignore the fact that, for Badiou, Paul and Christianity in general have no truth to tell for today. ${ }^{\text {clxxxix }}$

Badiou's attempt to "extract a formal, wholly secularized conception of grace"cxc from the Pauline texts and to exploit their political potential while disregarding Paul's theological commitments stems, basically, from his rejection of transcendence as such. Bonhoeffer's nonreligious interpretation aimed to redefine God's transcendence understood in a sense of other-worldliness so that it could be found in immanence ("God is beyond even in the middle of our lives"cxci), that is to say, in the "neighbor who is within reach in any given situation." ${ }^{\text {cxcii }}$ The God of Bonhoeffer is, in a sense, an absent God, a God who in the midst of the world remains invisible and silent until Christians make God present and visible by their participation in Jesus's being for others. While Bonhoeffer radically reinterprets the traditional Christian notion of transcendence, Badiou simply does away with it. In this regard, he represents "a shared new determination to grapple with the legacy of the death of God in a deeper way than ever before, re-making philosophy from the ground up as a thinking 'without God'." ${ }^{\text {xciii }}$ When Badiou speaks of the "death of God," what he means by "God" is not only the metaphysical God with whose death Nietzsche and Heidegger were concerned (the end of onto-theology) and whose death enables the return of a "more divine" God. In light of his 
ontology, all three meanings of the word "God" that he distinguishes, i.e., the living God of religion, the conceptual God of metaphysics, and the God of the poets, become superfluous. ${ }^{\text {cxciv }}$ As a consequence, even theological understanding of religion-as, for instance, "a personal communion between God and human beings" (Schillebeeckx ${ }^{\text {cxcv }}$-which could be accepted by Bonhoeffer, cannot stand in the face of Badiou's radical dismissal of transcendence. However, when we look at the reality of God, not from the point of view of objective truth, but from that of human experience, the experience of this-worldliness, we can discover in Badiou's writings a philosophical description of what Bonhoeffer theologically depicts as a world in which God is not graspable outside of the disciples' commitment to follow in the footsteps of Christ. Although, as Bell rightly points out, "Badiou's mathematized grace can actually promise nothing in the way of deliverance," ${ }^{\text {cxcvi }}$ Badiou opens, nonetheless, a radical possibility of thinking the nearness of grace with or without the existence of God. ${ }^{\text {cxcvii }}$ Whether Christian theology can engage with such a discourse about grace conceived of as radically immanent without compromising its identity and integrity, remains arguable. ${ }^{\text {cxcviii }}$

As I have attempted to show, one of the most valuable and lasting contributions of both Bonhoeffer and Badiou consists in their negative and anti-idolatrous insights. Attentive listening to Bonhoeffer's critique of religion and Badiou's reflection on evental grace that escapes the logic of traditional discourses and reflecting on the trajectory of thought indicated by the two of them may help Christian theology to avoid both the universal and specifically contemporary "religious trappings." Without a doubt, from the Catholic point of view the notions of religionless Christianity and immanent grace are eliciting more questions than answers. At the same time, however, both Bonhoeffer and Badiou make us face the right questions, the questions that are relevant to our contemporary condition. The "world come of age" needs a "Christianity come of age," a church built on worldly faith in the "resurrection 
truth-event" that can stand together as a global community, as a site of both contestation and reconciliation.

\footnotetext{
${ }^{\mathrm{i}}$ Irenaeus of Lyons, Against Heresies, Book 4, 20:7.

${ }^{i i}$ Dietrich Bonhoeffer, Dietrich Bonhoeffer Works-English, ed. and trans. by Gerhard Ludwig Müller et al. (Minneapolis: Fortress Press, 1996-2010) [=DBW-English], 6.55.
}

iii Alain Badiou, Saint Paul. The Foundation of Universalism, trans. Ray Brassier (Stanford, California: Stanford University Press, 2003), 62.

${ }^{\text {iv }}$ Cf. Ralf K. Wüstenberg, A Theology of Life: Dietrich Bonhoeffer's Religionless Christianity, trans. Doug Stott (Grand Rapids, Michigan and Cambridge, U.K.: William B Eerdmans Publishing Company, 1998), xiii-xiv. The fragmentary, unsystematic nature of Bonhoeffer's thought explains to an extent this ambivalence.

${ }^{v}$ Cf. Wüstenberg, A Theology of Life, xiv. Without doubt, Eberhard Bethge, the man to whom the prison letters were addressed and who was Bonhoeffer's closest friend, remains in many regards one of the most authoritative interpreters of Bonhoeffer's theology.

${ }^{v i}$ Dietrich Bonhoeffer, Letters and Papers from Prison, The Enlarged Edition, ed. Eberhard Bethge, trans. Reginald Fuller (New York: The Macmillan Company, 1971), 279.

${ }^{\text {vii }}$ Cf. Wüstenberg, A Theology of Life, 30.

${ }^{\text {viii }}$ Cf. Jeffrey C. Pugh, Religionless Christianity. Dietrich Bonhoeffer in Troubled Times (London: T\&T Clark International, 2008), xiv; 36.

${ }^{\text {ix }}$ Cf. Pugh, Religionless Christianity, 53.

$\mathrm{x}$ "...there remain only a few 'last survivors of the age of chivalry', or a few intellectually dishonest people, on whom we can descend as 'religious'." Bonhoeffer, Letters, 280.

${ }^{x i}$ Dietrich Bonhoeffer, Widerstand und Ergebung. Neuausgabe (Munich: Kaiser, 1985) [=WEN], 396, quoted in Wüstenberg, A Theology of Life, 154.

${ }^{x i i}$ DBW-English, 8.404. Cf. Pugh, Religionless Christianity, 45. "Man (sic) has learnt to deal with himself in all questions of importance without recourse to the 'working hypothesis' called 'God'" Bonhoeffer, Letters, 325.

${ }^{x i i i}$ Wüstenberg, A Theology of Life, 27. According to Bonhoeffer, there no longer can be any general concept of religion. His own understanding of religion often appears to be ambivalent, like in his famous statement from 1928: "Religion is at once both the most grandiose and the most tender of all human attempts to get at the eternal from within the anxiety and disquietude of the human heart." Dietrich Bonhoeffer, Dietrich Bonhoeffer Werke in 16 volumes (Munich: Christian Kaiser, 1986ff.) [=DBW-German], 10.455-60 (457), quoted in Wüstenberg, A Theology of Life, 3.

${ }^{\text {xiv }}$ Statements reflecting the first phase are to be interpreted against the background of liberal theology (A. von Harnack, A. Ritschl); statements critical of religion arose mostly under the influence of dialectical theology (K. Barth), whereas his thesis of religionlessness presupposes philosophical historicism (W. Dilthey, W. James). Cf. Wüstenberg, A Theology of Life, 97-98.

${ }^{x v}$ Cf. Pugh, Religionless Christianity, 84. From his prison cell at Tegel, Bonhoeffer confesses: "I will definitely not emerge from here as a 'homo religiosus'! Quite the contrary, here my distrust and anxiety with regard to 'religiosity' has become greater than ever" Bonhoeffer, Letters, 135.

${ }^{\mathrm{xvi}}$ Cf. Wüstenberg, A Theology of Life, 54; 127.

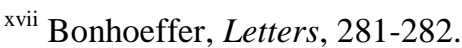


xviii Broadly speaking, Barth's dialectical theology mediated the phenomenalism of Kant to Bonhoeffer. Cf. Wüstenberg, A Theology of Life, 96. For the significance of Barth in Bonhoeffer's critique of religion see Wüstenberg, A Theology of Life, 31-68.

${ }^{\text {xix }}$ Cf. Wüstenberg, A Theology of Life, 99.

${ }^{\mathrm{xx}}$ Wüstenberg, A Theology of Life, 92.

${ }^{x x i}$ Pugh, Religionless Christianity, 74.

xxii Bonhoeffer, Letters, 280. Religion became a substitute for faith, a cultural artefact reducible to what anthropology, psychology or a host of other academic disciplines interpret it to be. Cf. Pugh, Religionless Christianity, 74.

${ }^{x x i i i}$ Cf. Wüstenberg, A Theology of Life, 57.

${ }^{x x i v}$ Cf. Frederik Depoortere, Badiou and Theology (New York: T\&T Clark International, 2009), 5.

${ }^{\mathrm{xxv}}$ Cf. Alain Badiou, Ethics: An Essay on the Understanding of Evil, trans. Peter Hallward (London: Verso, 2001), 40.

${ }^{x x v i}$ Cf. L. L. Welborn, "Extraction from the Mortal Site: Badiou on the Resurrection in Paul," New Testament Studies 55 (2009): 297.

xxvii Badiou, Ethics, 41. Badiou gives examples of what can count as 'truth-events' from the realms of politics, love, science, and art: the French Revolution of 1792, the meeting of Heloise and Abelard, Galileo's creation of physics, and Haydn's invention of the classical musical style. Cf. Badiou, Ethics, 41.

xxviii Alain Badiou, Infinite Thought: Truth and the Return of Philosophy, ed. and trans. Olivier Feltham and Justin Clemens (London and New York: Continuum, 2003), 50.

xxix Thus in contrast with what he regards as the mistaken emphasis placed by much of the Western philosophical tradition on the category of Being, Badiou assigns the central position in the search for truth to the category of Event. Cf. Stephen Chester, "Who is Freedom For? Martin Luther and Alain Badiou on Paul and Politics," in Paul, Grace and Freedom: Essays in Honour of John K. Riches, ed. Paul Middleton et al. (London and New York: T\&T Clark, 2009), 102.

${ }^{\mathrm{xxx}}$ Cf. Depoortere, Badiou and Theology, 7-8.

${ }^{x x x i}$ Cf. Adam Miller, Badiou, Marion and St Paul: Immanent Grace (London and New York: Continuum, 2008), 3; 21.

${ }^{x x x i i}$ Cf. Miller, Badiou, Marion and St Paul, 18; Depoortere, Badiou and Theology, 95. "Badiou's project necessarily implicates mathematics, but it is itself philosophical rather than mathematical. 'Mathematical fragments' are employed, but always according to philosophical rules." Miller, Badiou, Marion and St Paul, 117.

xxxiii Miller, Badiou, Marion and St Paul, 18. Cantor claimed that we need to postulate God to solve the so-called problem of paradoxical sets.

${ }^{\text {xxxiv }}$ Cf. Miller, Badiou, Marion and St Paul, 116; 37.

${ }^{x x x v}$ Cf. Alain Badiou, Being and Event, trans. Olivier Feltham (London: Continuum, 2005), 4; Cf. Chester, "Who is Freedom For?," 102.

${ }^{x x x v i}$ Depoortere, Badiou and Theology, 8. "The concept of universalism, so central to Badiou, first entered Pauline studies in the work of F.C. Baur (1792-1860) as an analytical tool by means of which to access the historical significance of Paul in terms other than those of orthodox Christian theology. Since then, the 
recurrence of the concept of universalism as the key to understanding Paul has been striking" Chester, "Who is Freedom For?," 107.

xxxvii Ola Sigurdson suggests that the particular theological tradition to which these non-theological readings of Paul seem indebted has been founded by Rudolf Bultmann. Cf. Ola Sigurdson, "Reading Žižek Reading Paul," in David Odell-Scott, ed., Reading Romans with Contemporary Philosophers and Theologians (London: T\&T Clark International, 2007), 222. Cf. also Badiou, Saint Paul, 4.

xxxviii Cf. Miller, Badiou, Marion and St Paul, 21. "Badiou's treatment of Paul substantially illustrates many of his central ideas and the relative familiarity of its Pauline terminology productively counter-balances the rarified formality of Being and Event." Miller, Badiou, Marion and St Paul, 144-145.

${ }^{\text {xxxix }}$ Cf. Depoortere, Badiou and Theology, 9.

${ }^{\mathrm{xl}}$ Depoortere, Badiou and Theology, 8-9. Thus in Badiou's Saint Paul, the philosopher applies his theory of "truth processes" to the founder of Christianity. Cf. Welborn, "Extraction from the Mortal Site,” 295.

xli Badiou, Saint Paul, 2.

xlii Sigurdson, "Reading Žižek Reading Paul," 219.

xliii Cf. John K. Riches, "Paul, Grace and Freedom: A Response," in Paul, Grace and Freedom, ed. Middleton, 193.

${ }^{\text {xliv }}$ Badiou, Saint Paul, 4; 66.

${ }^{x l v}$ Cf. Badiou, Saint Paul, 12. Cf. also Chester, "Who is Freedom For?," 106.

${ }^{x l v i}$ In this context, Žižek's objection to Badiou's interpretation of Paul seems more than relevant. Cf. Slavoj Žižek, The Ticklish Subject: The Absent Center of Political Ontology (London and New York: Verso, 2000), 143-144.

xlvii Chester, "Who is Freedom For?," 109.

xlviii I will attempt to accomplish this task with the help of other theological interpretations of Badiou.

${ }^{\text {xlix }}$ Cf. William A. Walker, "Alan Badiou on Saint Paul's Event: A New Christian Politic?, " available online on http://billwalker.wordpress.com/2011/05/02/alan-badiou-on-saint-paul\%E2\%80\%99s-event-a-new-christianpolitic/ accessed on 23.01.2013. However, as Paula Fredriksen puts it, this is tolerable "if only they would confess that it is they who speak, not the apostle," John D. Caputo and Linda Martín Alcoff, St. Paul Among the Philosophers, (Bloomington: Indiana University Press, 2009), 19.

${ }^{1}$ Cf. Chester, "Who is Freedom For?," 108.

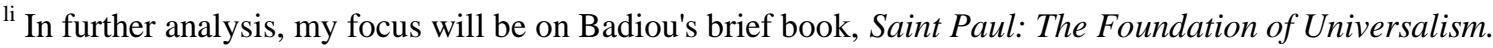
Nonetheless, one should keep in mind that his doctrine of the event cannot be understood in isolation from his 'mathematized ontology' of which his interpretation of Paul is only an illustration. Cf. Depoortere, Badiou and Theology, 9-10.

lii $D B W$-English, 8.455. Thus the concept of the 'world come of age' can be understood both historically as the end of a specific world-historical development and Christologically as the beginning of the salvific-historical development. Cf. Wüstenberg, A Theology of Life, 70.

\footnotetext{
liii Badiou, Saint Paul, 5.

liv WEN, 412, quoted in Wüstenberg, A Theology of Life, 135.

lv WEN, 396, quoted in Wüstenberg, A Theology of Life, 100.
} 
${ }^{\text {lvi }}$ Cf. Wüstenberg, A Theology of Life, 100.

lvii WEN, 395, quoted in Wüstenberg, A Theology of Life, 131.

lviii Cf. Sabine Dramm, Dietrich Bonhoeffer: An Introduction to his Thought, trans. Thomas Rice (Peabody, Mass: Hendrickson, 2007), 198 (italics in the original).

lix Bonhoeffer, Ethics, 55.

${ }^{1 x}$ DBW-English, 6.47 .

${ }^{1 \times i} D B W$-English, 6.40-41.

${ }^{\text {Ixii }}$ Friedrich Nietzsche, The Anti-Christ, §42, quoted in Badiou, Saint Paul, 61.

lxiii Badiou, Saint Paul, 62.

${ }^{\text {Ixiv }}$ Badiou, Saint Paul, 62.

${ }^{\mathrm{lxv}}$ Badiou, Being and Event, 143. Badiou argues that in Paul's logic one must "go so far as to say that the Christevent testifies that God is not the god of Being, is not Being. Paul prescribes an anticipatory critique of what Heidegger calls onto-theology." Badiou, Saint Paul, 47.

${ }^{1 x v i}$ Cf. Miller, Badiou, Marion and St Paul, 117-119.

${ }^{1 x v i i}$ Cf. Miller, Badiou, Marion and St Paul, 118.

${ }^{1 x v i i i}$ Cf. Miller, Badiou, Marion and St Paul, 3-4.

${ }^{\text {Ixix }}$ Cf. Miller, Badiou, Marion and St Paul, 152.

${ }^{1 x x}$ Miller, Badiou, Marion and St Paul, 16.

${ }^{1 x x i}$ Miller, Badiou, Marion and St Paul, 17.

Ixxii DBW-English, 4.181 .

lxxiii In fact, Bonhoeffer's ecclesiology relativizes, in a sense, all ethical systems: "God has founded His (sic) church beyond all religion and ethics" DBW-English, 15.459.

${ }^{\text {lxxiv }} D B W$-German, 10.302-322, quoted in Wüstenberg, A Theology of Life, 3.

${ }^{\text {lxxv }}$ Cf. Badiou, Saint Paul, 46.

${ }^{1 x x v i}$ Badiou, Saint Paul, 46.

lxxvii Badiou, Saint Paul, 45.

Ixxviii Badiou, Saint Paul, 54.

${ }^{\text {Ixxix }}$ DBW-German, 10.459, quoted in Wüstenberg, A Theology of Life, 41. Cf. also Pugh, Religionless Christianity, 77. In this context, Bonhoeffer speaks of the great antithesis of the word of God and the word of man, of grace and religion.

${ }^{1 x x x}$ Therefore, Bonhoeffer concludes, "if human beings and God are to come together, there can be but one path: God's path to human beings." DBW-German, 10.315, quoted in Wüstenberg, A Theology of Life, 3.

${ }^{\text {Ixxxi }} \mathrm{Cf}$. Wüstenberg, A Theology of Life, 51; 54. "The 'religious act' is always something partial, while 'faith' is something whole, an act of life." Bonhoeffer, Letters, 362. 
${ }^{\text {lxxxii }}$ Cf. Pugh, Religionless Christianity, 80.

lxxxiii Cf. Bonhoeffer, Letters, 280. "To interpret religiously means to speak metaphysically on the one hand, and individualistically on the other" Bonhoeffer, Letters, 283. The former is interpreted under the aspects of 'deus ex machina', 'stopgap', and the working hypothesis 'God', while the latter is seen under the aspects of 'something partial,' 'religiously privileged,' and guardianship of 'God' Cf. Wüstenberg, A Theology of Life, 22.

${ }^{\text {lxxxiv }}$ Dramm, Dietrich Bonhoeffer, 200.

${ }^{\operatorname{lxxxv}}$ By using afterlife or personal salvation as the ultimate end religious interpretation sacrifices the penultimate on the altar of the ultimate. Cf. Pugh, Religionless Christianity, 104.

${ }^{1 x x x v i}$ Dietrich Bonhoeffer, Gesammelte Schriften. Edited by Eberhard Bethge. 6 vols. (Munich: Kaiser, 19581974), 5.303, quoted in Wüstenberg, A Theology of Life, 8. Cf. Dramm, Dietrich Bonhoeffer, 196.

lxxxvii DBW-German, 10.319, quoted in Wüstenberg, A Theology of Life, 37.

lxxxviii Badiou, Saint Paul, 49.

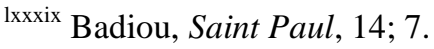

${ }^{x c}$ Cf. Miller, Badiou, Marion and St Paul, 138. As a consequence, the evental quality can be solidified only by the community that has been held together by the event and engaged on its behalf. Cf. Walker, "Alan Badiou on Saint Paul's Event."

${ }^{\text {xci }}$ Cf. Badiou, Saint Paul, 63-4.

${ }^{x c i i}$ Cf. Badiou, Saint Paul, 51; 58.

xciii Badiou, Saint Paul, 52.

${ }^{\text {xciv }}$ Badiou, Saint Paul, 83.

${ }^{\mathrm{xcv}}$ Cf. Miller, Badiou, Marion and St Paul, 145-146.

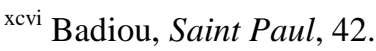

${ }^{\text {xcvii }}$ Cf. Miller, Badiou, Marion and St Paul, 146.

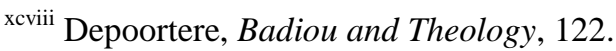

${ }^{x c i x}$ Badiou, Ethics, 69.

${ }^{\text {c }}$ Cf. Badiou, Saint Paul, 108. Cf. also Žižek, The Ticklish Subject, 143-144.

ci Welborn, "Extraction from the Mortal Site," 298.

cii Cf. Kenneth A. Reynhout, "Alain Badiou: Hidden Theologian of the Void?," Heythrop Journal 52, no. 2 (2011): 219-233.

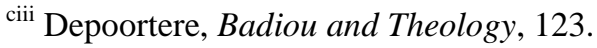

${ }^{\text {civ }}$ Cf. Wüstenberg, A Theology of Life, 160.

${ }^{\mathrm{cv}}$ Cf. Wüstenberg, A Theology of Life, 119.

${ }^{\mathrm{cvi}}$ WEN, 414, quoted in Wüstenberg, A Theology of Life, 151. 


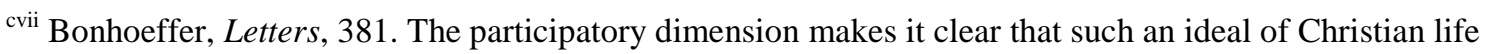
cannot be simply reduced to an ethical attitude but has its deeply mystical component. Cf. Pugh, Religionless Christianity, 102.

cviii Cf. Dramm, Dietrich Bonhoeffer, 193.

${ }^{\text {cix } W E N, ~ 328, ~ q u o t e d ~ i n ~ W u ̈ s t e n b e r g, ~ A ~ T h e o l o g y ~ o f ~ L i f e, ~} 86$.

${ }^{\mathrm{cx}}$ Badiou, Saint Paul, 14.

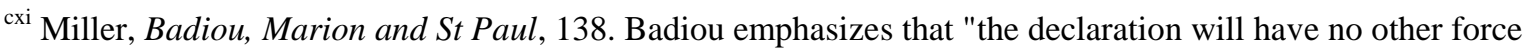
than the one it declares." Badiou, Saint Paul, 53.

${ }^{\text {cxii }}$ Cf. Badiou, Saint Paul, 14-18.

${ }^{\text {cxiii }}$ Cf. Badiou, Saint Paul, 51.

${ }^{\text {cxiv }}$ Cf. Rom. 10:9-10; Badiou, Saint Paul, 88.

${ }^{c x v}$ In this context, Žižek's twofold objection seems quite relevant: First, "Is not the true fidelity to the Event 'dogmatic' in the precise sense of unconditional faith, of an attitude that does not ask for good reasons and that, for that very reason, cannot be refuted by any argumentation?" John Milbank, Slavoj Žižek, and Creston Davis, Paul's New Moment: Continental Philosophy and the Future of Christian Theology (Grand Rapids, MI: Brazos Press, 2010), 90-91. And second, "Is not the circular relationship between the Event and the subject (the subject serves the Event in his or her fidelity, but the Event itself is visible as such only to an already engaged subject) the very circle of ideology?" Milbank et al., Paul's New Moment, 92.

${ }^{\text {cxvi }}$ Cf. Miller, Badiou, Marion and St Paul, 139; 147.

cxvii Badiou, Being and Event, 233.

cxviii Miller, Badiou, Marion and St Paul, 140.

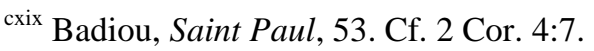

${ }^{\mathrm{cxx}}$ Badiou, Saint Paul, 46.

${ }^{c x x i}$ Badiou, Saint Paul, 110.

cxxii WEN, 395, quoted in Wüstenberg, A Theology of Life, 131.

cxxiii Badiou, Saint Paul, 52.

${ }^{\text {cxxiv }}$ Badiou, Saint Paul, 52. This aspect of Badiou's thought overlaps, for example, with Caputo's concept of weak theology. Cf. John D. Caputo, The Weakness of God: A Theology of the Event (Bloomington: Indiana University Press, 2006).

${ }^{\mathrm{cxxv}}$ Cf. Wüstenberg, A Theology of Life, 89.

${ }^{\text {cxxvi }}$ Cf. Pugh, Religionless Christianity, 101.

cxxvii WEN, 395, quoted in Wüstenberg, A Theology of Life, 131.

${ }^{\text {cxxviii }}$ Cf. Pugh, Religionless Christianity, 113. Bonhoeffer himself learned to see the events of history "from the perspective of the outcasts, the suspects, the maltreated, the powerless, the oppressed, the reviled-in short, from the perspective of those who suffer" Bonhoeffer, Letters, 17.

${ }^{\text {cxxix }}$ Cf. Bonhoeffer, Letters, 361. 
${ }^{\text {cxxx }}$ Cf. Eberhard Bethge, Dietrich Bonhoeffer: A Biography, rev. and ed. By Victoria Barnett (Minneapolis, MN: Fortress Press, 2000), 117; Pugh, Religionless Christianity, 78.

${ }^{\text {cxxxi }}$ Cf. Pugh, Religionless Christianity, 104; 132.

cxxxii Pugh, Religionless Christianity, 136.

cxxxiii DBW-English, 6.49-50.

${ }^{\text {cxxxiv }}$ Cf. Wüstenberg, A Theology of Life, 67.

${ }^{\text {cxxxv }}$ WEN, 375, quoted in Wüstenberg, A Theology of Life, 128.

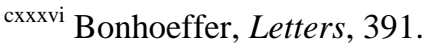

${ }^{\text {cxxxvii }}$ Cf., for instance, Bonhoeffer, Ethics, 132.

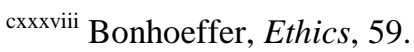

${ }^{\text {cxxxix }}$ Wüstenberg, A Theology of Life, 157. This resonates with the famous Ebeling's admonition that the nonreligious interpretation is for Bonhoeffer nothing other than Christological interpretation. Cf. Wüstenberg, $A$ Theology of Life, xiv-xv.

${ }^{\mathrm{cxl}}$ Cf. Badiou, Saint Paul, 42.

cxli Badiou, Saint Paul, 59.

${ }^{\text {cxlii }}$ Cf. Badiou, Saint Paul, 18-19.

cxliii Badiou, Saint Paul, 53; 52. "Paul himself teaches us that it is not the signs of power that count, nor exemplary lives, but what a conviction is capable of, here, now, and forever." Badiou, Saint Paul, 30.

${ }^{\text {cxliv }}$ Cf. Badiou, Being and Event, 222.

cxlv Chester, "Who is Freedom For?," 98; 102.

cxlvi Gordon Zerbe, "On the Exigency of a Messianic Ecclesia: An Engagement with Philosophical Readers of Paul," in Douglas Karel Harink, Paul, Philosophy, and the Theopolitical Vision: Critical Engagements with Agamben, Badiou, Žižek, and others (Eugene, Or: Cascade Books, 2010), 279.

cxlvii Badiou, Saint Paul, 53.

cxlviii Kyle Gingerich Hiebert, "Capitalism and Catholicity: Ecclesiological Reflections on Alain Badiou's Pauline Universalism," New Blackfriars 92, no. 1041 (2011): 580. Ultimately, an event thus comprehended is, for Badiou, the only thing that really matters: "What constitutes an event in Christ is exclusively the Resurrection, that anastasis nekōn that should be translated as the rising up of the dead ... which is the uprising of life," Badiou, Saint Paul, 68.

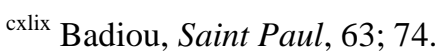

${ }^{\mathrm{cl}}$ Cf. Badiou, Saint Paul, 60.

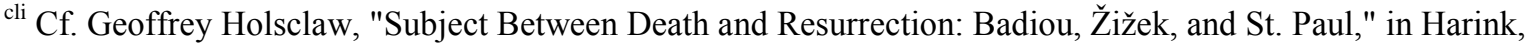
Paul, Philosophy, and the Theopolitical Vision, 159.

clii Cf., inter alia, Chester, "Who is Freedom For?"; Zerbe, "On the Exigency of a Messianic Ecclesia"; Hiebert, "Capitalism and Catholicity." 
cliii Cf. Chester, "Who is Freedom For?," 114. Besides, as he argues, "resurrection might be excluded by Gentile discourse, but it could amply fulfill the Jewish demand for miraculous signs (1 Cor. 1:22). ... It is its proclamation in conjunction with the cross, as the resurrection of a crucified Messiah, which excludes it from all existing discourses of truth and not merely from some. ... The creation of the subject requires that the selfgiving love of the cross be fully incorporated into the Event." Chester, "Who is Freedom For?," 110-111.

${ }^{\text {cliv }}$ Cf. Zerbe, "On the Exigency of a Messianic Ecclesia," 279.

clv Welborn, "Extraction from the Mortal Site," 296.

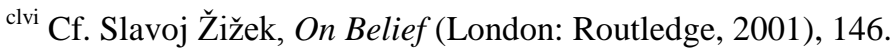

${ }^{c l v i i} W E N, 415$, quoted in Wüstenberg, A Theology of Life, 155.

clviii Bethge, Dietrich Bonhoeffer, 236.

${ }^{\text {clix }}$ Cf. Pugh, Religionless Christianity, 75; 160.

${ }^{\mathrm{clx}}$ Bonhoeffer, Ethics, 331 .

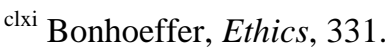

${ }^{\text {clxii }}$ Cf. Pugh, Religionless Christianity, 92.

clxiii Bonhoeffer, Gesammelte Schriften, 4.431, quoted in Wüstenberg, A Theology of Life, 13.

${ }^{\text {clxiv }}$ Pugh, Religionless Christianity, 93.

${ }^{c l x v}$ Cf. Pugh, Religionless Christianity, 81.

clxvi Pugh, Religionless Christianity, 146.

${ }^{c l x v i i}$ Cf. Bonhoeffer, Letters, 286.

clxviii Cf. Walker, "Alan Badiou on Saint Paul's Event."

${ }^{\text {clxix }}$ Cf. Joseph Moingt, "Laisser Dieu s'en aller," Dieu, Église, Société (1985): 275-286.

${ }^{\mathrm{clxx}}$ Cf. Dramm, Dietrich Bonhoeffer, 199.

${ }^{c l x x i}$ Chester, "Who is Freedom For?," 105.

clxxii Badiou, Saint Paul, 15.

clxxii Badiou, Saint Paul, 15.

${ }^{\text {clxxiv }}$ Hiebert, "Capitalism and Catholicity," 581.

${ }^{\mathrm{clxxv}}$ Cf. Hiebert, "Capitalism and Catholicity," 585.

${ }^{c 1 x x v i}$ Hiebert, "Capitalism and Catholicity," 588.

clxxvii Slavoj Žižek, The Puppet and the Dwarf: The Perverse Core of Christianity (Cambridge: The MIT Press, 2003), 109 .

clxxviii Cf. Hiebert, "Capitalism and Catholicity," 589. As Badiou admonishes, following Paul's proclamation that God's foolishness is wiser than human wisdom and God's weakness is stronger than human strength (cf. 1 Cor. 1:25), we must dispense with every formula of mastery. Cf. Badiou, Saint Paul, 58-59. 
clxxix Terry Eagleton, Sweet Violence: The Idea of the Tragic (Oxford: Blackwell, 2003), 165.

${ }^{\text {clxxx }}$ Cf. Hiebert, "Capitalism and Catholicity," 589-590.

clxxxi Cf. Tomáš Halík, Patience with God: The Story of Zacchaeus Continuing in Us (New York, London, Toronto, Sydney, Auckland: Doubleday, 2009), 50-51.

${ }^{\text {clxxxii } D B W-E n g l i s h, 10.320 .}$

clxxiii Cf. Halík, Patience with God, 50. Paul had the courage to reject all previous 'certainties' and the 'quiescence of compromise' as a temptation-a temptation to seek salvation elsewhere than in the reconciliation of God with the world through Christ's cross. Cf. Halík, Patience with God, 51.

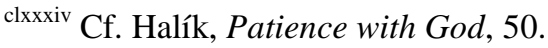

${ }^{\text {clxxx }}$ Miller, Badiou, Marion and St Paul, 1.

clxxxvi Hiebert, "Capitalism and Catholicity," 590.

clxxxii Peter Hallward, Badiou: A Subject to Truth (Minneapolis: University of Minnesota Press, 2003), xxiv.

clxxxviii Cf. Depoortere, Badiou and Theology, 9; 22.

clxxxix The contingent nature of truth means that although the "Christian fable" was once true, it is not relevant anymore. Cf. Chester, "Who is Freedom For?," 106.

${ }^{\mathrm{cxc}}$ Badiou, Saint Paul, 4; 66.

${ }^{\text {cxci } W E N, ~ 308, ~ q u o t e d ~ i n ~ W u ̈ s t e n b e r g, ~ A ~ T h e o l o g y ~ o f ~ L i f e, ~} 120$.

${ }^{\text {cxcii }}$ Bonhoeffer, Letters, 381.

cxciii Christopher Watkin, Difficult Atheism: Post-theological Thinking in Alain Badiou, Jean-Luc Nancy and Quentin Meillassoux (Edinburgh: Edinburgh University Press, 2011), 240.

${ }^{\text {cxciv }}$ Cf. Depoortere, Badiou and Theology, 17-18.

${ }^{\text {cxcv }}$ Edward Schillebeeckx, Revelation and Theology. Theological Soundings 1.1 (London and Melbourne: Sheed and Ward, 1967), 103.

cxcvi Daniel M. Bell, Jr., "Badiou's Faith and Paul's Gospel: The Politics of Indifference and the Overcoming of Capital," Angelaki 12, no. 1 (2007): 104.

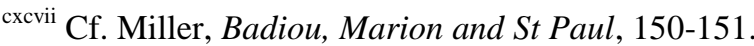

${ }^{\text {cxcviii }}$ Cf. Depoortere, Badiou and Theology, 123-124. 